\title{
A Comparison of Off-Grid-Pumped Hydro Storage and Grid-Tied Options for an IRSOFC-HAWT Power Generator
}

\author{
Mahdi Majidniya, ${ }^{1}$ Kobra Gharali, ${ }^{1}$ and Kaamran Raahemifar ${ }^{2}$ \\ ${ }^{1}$ Department of Mechanical Engineering, University of Tehran, Tehran, Iran \\ ${ }^{2}$ Department of Electrical \& Computer Engineering, Ryerson University, Toronto, ON, Canada \\ Correspondence should be addressed to Kobra Gharali; kgharali@ut.ac.ir
}

Received 7 April 2017; Revised 12 May 2017; Accepted 4 June 2017; Published 10 July 2017

Academic Editor: Yuanzheng Li

Copyright (c) 2017 Mahdi Majidniya et al. This is an open access article distributed under the Creative Commons Attribution License, which permits unrestricted use, distribution, and reproduction in any medium, provided the original work is properly cited.

An Internal Reforming Solid Oxide Fuel Cell (IRSOFC) is modeled thermodynamically; a Horizontal Axis Wind Turbine (HAWT) is designed; the combined IRSOFC-HAWT system should create a reliable source of electricity for the demand of a village located in Manjil, Iran. The output power of HAWT is unstable, but by controlling the fuel rate for the IRSOFC it is possible to have a stable power output from the combined system. When the electricity demand is over the peak or the wind speed is low/unstable/significantly high, the generated power may not be sufficient. To solve this problem, two scenarios are considered: connecting to the grid or using a Pumped Hydro Storage (PHS). For the second scenario, the extra produced electricity is saved when the production is more than demand and can be used when the extra power is needed. The economic analysis is done based on the economic conditions in Iran. The results will show a period of return about 9.5 and 13 years with the levelized cost of electricity about 0.0747 and $0.0882 \$ / \mathrm{kWh}$ for the first and second scenarios, respectively. Furthermore, effects of some parameters such as the electricity price and the real interest rate are discussed.

\section{Introduction}

Making a balance between energy productions and energy demands is a challenging issue for Renewable Energy (RE) systems. Energy production from RE sources is affected by low efficiencies, high capital costs, unreliable energy sources, and environmental impacts. Recently, combined systems are introduced to create efficient and economical power sources and mostly to overcome the unreliability of RE systems such as wind turbines. Based on the local conditions and the main energy source, the way that systems are combined varies. One of the options is combining the systems with a fuel cell. A fuel cell is a Renewable Energy source with controllable output electricity. A fuel cell has a short startup time. It is possible to add or remove cells immediately from the power cycle without any trouble. An SOFC is a common type of fuel cells for power plant applications. Recent studies include an SOFC in the power generation systems. In the following, some of the recent combinations of SOFC with other systems are discussed.
Soheyli et al. [1] analyzed a combined system in a hypothetical hotel in Kermanshah, Iran. The final optimized system was a combination of 10 wind turbines, $430 \mathrm{PV}$ modules, 11 SOFCs, 106 batteries, and 2 heat storage tanks. Their results showed that the fuel consumption and pollution were decreased 263 and 353 times, respectively. Fathy [2] studied a system including photovoltaic modules, wind turbines, and fuel cells in Egypt. Obara et al. [3] used a numerical analysis to stabilize photovoltaic cyclic fluctuations by using a governor-free control of an SOFC and a flywheel inertia system. Hosseini et al. [4] analyzed a combination of photovoltaic-electrolyzer, SOFC, and a heat recovery unit for a residential area. The system supported an absorption chiller and a heat recovery steam generator using the excess heat of an SOFC. They conducted an energy and exergy analysis of the system. Vigneysh and Kumarappan [5] studied a combination of photovoltaic cells, an SOFC, and a battery energy storage system. For making a balance between power generation and consumption, a fuzzy logic method was applied. The SOFC was a backup generator. It reached its 


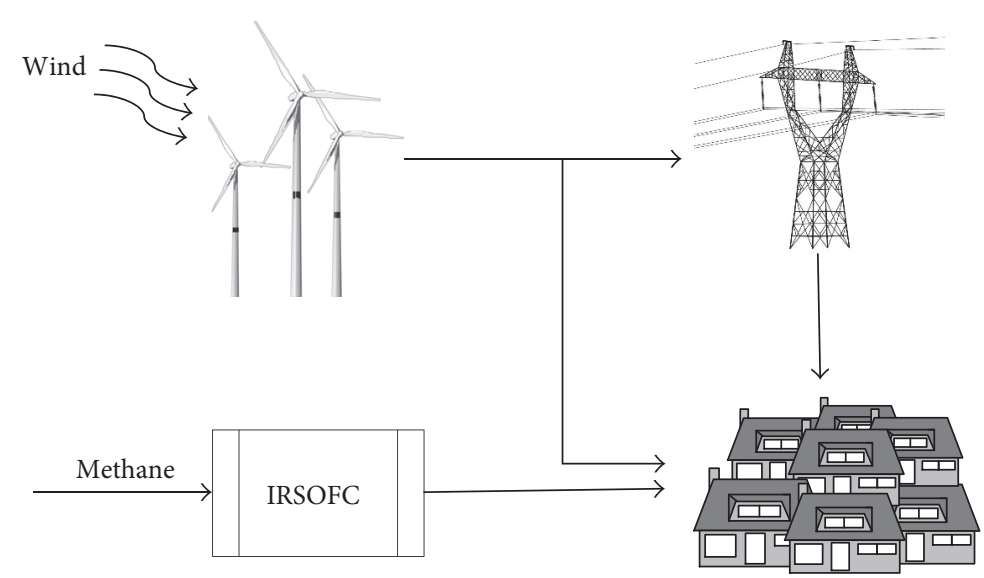

(a)

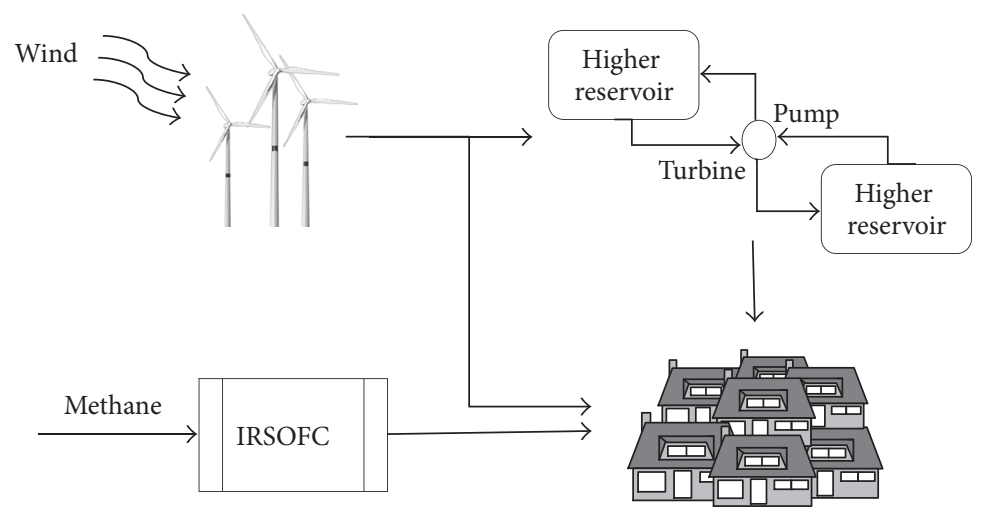

(b)

FIGURE 1: Schematic of the system: (a) first scenario and (b) second scenario.

rated power when the charge of the battery energy storage system was at the minimum limit. Tenfen and Finardi [6] presented a mathematical model to manage the energy from a microgrid. They modeled a micro turbine and an SOFC and combined them with a battery bank, photovoltaic cells, and a wind turbine. Akikur et al. [7] developed a mathematical model for a reversible SOFC combined with photovoltaic cells. To produce $100 \mathrm{~kW}$ of electricity, they investigated thermodynamically and economically three modes: a solarSOFC mode for low solar radiation, a solar-solid oxide steam electrolyzer mode for high solar radiation, and an SOFC mode at night. Bai et al. [8] modeled and controlled an SOFC with photovoltaic cells. They used two PI controllers using an artificial bee colony.

It was shown that the combination of an SOFC with a wind turbine or photovoltaic cells is a state-of-the-art topic. In this study, a PHS is also added to a combined system of a HAWT and an IRSOFC. The system can run on grid or off grid with the aid of PHS as an energy storage component. The results are compared based on the economic and thermodynamic analysis to study the feasibility of each scenario; this comparison has not been done before based on the knowledge of the authors. In addition, the systems should fulfill the power demand of a village located in Manjil,
Iran. The parameters are chosen based on the local economic and environmental conditions, making this study unique. It should be noticed that the system is sized based on monthly average wind speed and the needed electricity. That means the wind speed may not always match the needed electricity. For solving this problem, the two following scenarios are introduced.

The First Scenario (Figure 1(a)). The system is connected to the grid. It is possible to sell and buy electricity from the grid. The electricity can be sold to the grid when the produced electricity is more than demand. The electricity can be bought from the grid when the production cannot meet the demand. It is assumed that the prices of the selling and buying electricity are the same.

The Second Scenario (Figure 1(b)). The system is not connected to the grid. The extra electricity production of the wind turbine is saved by a Pumped Hydro Storage (PHS) system and can be released when it is needed. A PHS is a system that contains a pump, a turbine, and two reservoirs, a higher reservoir and a lower one. During high electricity production, the PHS pumps the water from the lower reservoir to 
the higher one to save the energy. When the electricity is needed, the water goes from the higher reservoir to the lower one through a turbine. Because of the pump and the turbine efficiencies and the other losses, some of the energy will be lost during these processes. To make up this energy, the size of the HAWT has been increased. The size of the PHS is assumed to be equal to the maximum needed electricity minus maximum production of the IRSOFC.

The case study is to produce power for a village with 100 houses located in Manjil, Iran. An economic analysis will show the possibility of the study.

Based on two scenarios, the main components, the IRSOFC and the HAWT, are modeled and designed in Sections 2 and 3. The economic method is described in Section 4. After validating the IRSOFC and the HAWT in Section 5, the results of the modeling and the economic analysis are discussed in Section 6.

\section{Thermodynamic Modeling of IRSOFC}

The modeling of components is done by home codes. The assumptions of the fuel cell modeling are

(i) ideal gases,

(ii) linear variation of enthalpy,

(iii) working in a steady condition,

(iv) being isolated with no heat exchange,

(v) no contact resistance,

(vi) ignoring radiation heat transfer between the gas canal and the solid container,

(vii) tubular cells and stack.

2.1. Direct Internal Reformer. For a fuel cell consuming natural gas, an internal or an external reformer is needed. Since an external reformer needs a cooling system and is less cost-effective than an internal one, the internal reformers are preferred [9].

In the internal reforming process, the occurring reactions are very endothermic, while the heat is provided by the fuel cell. The reactions in this process are the steam reforming reaction $\left(x \Rightarrow \mathrm{CH}_{4}+\mathrm{H}_{2} \mathrm{O} \rightarrow \mathrm{CO}+3 \mathrm{H}_{2}\right)$ and the gas water shifting reaction $\left(y \Rightarrow \mathrm{CO}+\mathrm{H}_{2} \mathrm{O} \rightarrow \mathrm{CO}_{2}+\right.$ $\mathrm{H}_{2}$ ). According to these reactions, natural gas transforms to hydrogen in the fuel cell. Hydrogen takes part in an electrochemical reaction $\left(z \Rightarrow \mathrm{H}_{2}+(1 / 2) \mathrm{O}_{2} \rightarrow \mathrm{H}_{2} \mathrm{O}\right)$. Here, $x, y$, and $z$ are the molar rate progress of reforming, shifting, and electrochemical reactions, respectively [10]. This molar rate progress is calculated based on the relation among the equation constants, the temperature, and the pressure of the gasses.
TABLE 1: IRSOFC resistivity constants [12].

\begin{tabular}{lccc}
\hline & $A(\Omega \cdot \mathrm{cm})$ & $B(\mathrm{~K})$ & $\delta(\mathrm{cm})$ \\
\hline Anode & 0.00298 & 1392 & 0.01 \\
Cathode & 0.00811 & -600 & 0.19 \\
Electrolyte & 0.0294 & -10350 & 0.004 \\
Internal connections & 0.1256 & -4690 & 0.0085 \\
\hline
\end{tabular}

2.2. Reversible Voltage. The reversible voltage $\left(E_{\text {rev }}\right)$ of the cell can be found by using Nernst equation:

$$
\begin{aligned}
E_{\text {rev }} & =E^{\circ}+\Delta E=\frac{-\Delta G^{\circ}}{n_{e} F}+\frac{-\Delta G}{n_{e} F} \\
& =\frac{-\Delta G^{\circ}}{2 F}+\frac{R T}{2 F} \ln \frac{p_{\mathrm{H}_{2}} p_{\mathrm{O}_{2}}^{0.5}}{p_{\mathrm{H}_{2} \mathrm{O}}} .
\end{aligned}
$$

Because of the irreversibilities, the voltage of a real fuel cell is less than that of a reversible one. These irreversibilities are called overpotentials. Overpotentials can be divided into three categories: Ohmic $\left(\eta_{\mathrm{Ohm}}\right)$, activation $\left(\eta_{\text {Act }}\right)$, and concentration $\left(\eta_{\text {Conc }}\right)$. The magnitude of these overpotentials grows as current density increases, which results in reducing the voltage of the cell. The cell voltage can be described as ([11])

$$
E=E_{\text {rev }}-\left(\eta_{\text {Act }}+\eta_{\text {ohm }}+\eta_{\text {conc }}\right) .
$$

2.2.1. Ohmic Overpotential. Ohmic overpotential $\left(\eta_{\mathrm{Ohm}}\right)$ can be calculated as

$$
\eta_{\mathrm{Ohm}}=i r
$$

where $r$ is the resistance:

$$
r=\delta \rho .
$$

$\delta$ is the thickness (Table 1) of components and $\rho$ is the resistivity:

$$
\rho=A \exp \left(\frac{B}{T}\right) .
$$

$A$ and $B$ are resistivity constants (Table 1 ).

2.2.2. Activation Overpotential. Butler-Volmer equation [13] describes

$$
i=i_{0}\left\{\exp \left(\beta \frac{n_{e} F \eta_{\text {Act }}}{R T}\right)-\exp \left(-(1-\beta) \frac{n_{e} F \eta_{\text {Act }}}{R T}\right)\right\} .
$$

$\beta$ is the heat transfer coefficient and $i_{0}$ is the exchange current density. The heat transfer coefficient is the ratio of the exchange in the potential drop which results in changing the rate of constants. The value of $\beta$ for a fuel cell is 0.5 . For $\beta=0.5$, (6) can be

$$
i=2 i_{0} \sinh \left(\frac{n_{e} F \eta_{\text {Act }}}{2 R T}\right) .
$$


TABLE 2: Values of activation overpotential constants [11].

\begin{tabular}{lccc}
\hline & & Cathode & Anode \\
\hline$\gamma$ & $\mathrm{A} / \mathrm{m}^{2}$ & $1.49 \times 10^{10}$ & $2.13 \times 10^{8}$ \\
$E_{\text {Act }}$ & $\mathrm{kJ} / \mathrm{mol}$ & 110 & 160 \\
\hline
\end{tabular}

Therefore,

$$
\begin{aligned}
& \eta_{\text {Act }, \mathrm{An}}=\frac{2 R T}{n_{e} F} \sinh ^{-1}\left(\frac{i}{2 i_{0, \mathrm{An}}}\right), \\
& \eta_{\text {Act, } \mathrm{Ca}}=\frac{2 R T}{n_{e} F} \sinh ^{-1}\left(\frac{i}{2 i_{0, \mathrm{Ca}}}\right) .
\end{aligned}
$$
[13].

Equation (7) should be applied to both anode and cathode

$$
\begin{aligned}
& i_{0, \mathrm{An}}=\gamma_{\mathrm{An}}\left(\frac{p_{\mathrm{H}_{2}}}{p_{\text {ref }}}\right)\left(\frac{p_{\mathrm{H}_{2} \mathrm{O}}}{p_{\text {ref }}}\right) \exp \left(-\frac{E_{\mathrm{Act}, \mathrm{An}}}{R T}\right), \\
& i_{0, \mathrm{Ca}}=\gamma_{\mathrm{Ca}}\left(\frac{p_{\mathrm{O}_{2}}}{p_{\text {ref }}}\right)^{0.25} \exp \left(-\frac{E_{\mathrm{Act}, \mathrm{Ca}}}{R T}\right)
\end{aligned}
$$

$\gamma$ (preexponential factor) like the activation energy $\left(E_{\text {Act }}\right)$ depends on electrode materials [11] (Table 2).

2.2.3. Concentration Overpotential. Concentration overpotential can be calculated as

$$
\eta_{\text {Conc }}=\frac{R T}{n_{e} F}\left(1-\frac{i}{i_{l}}\right)
$$

where $i_{l}$ is the limiting current density. Considerable growth of concentration overpotential will be observed if the current density meets its limit.

\section{HAWT Modeling}

A home code for designing a HAWT is written based on Blade Element Momentum (BEM) method. For a rotor of a HAWT with the radius $(R)$, the blade should be divided into some sections or elements. Each section (i) has a distance $r$ from the hub of the rotor.

For each element, the local chord of the blade $(c(r))$ can be calculated from Schmitz formulation [14]:

$$
c(r)=\frac{8 \pi r}{N C_{L}}\left(1-\cos \left(\frac{2}{3} \tan ^{-1}\left(\frac{R}{r \lambda_{r}}\right)\right)\right) .
$$

$\lambda_{r}$ is the local tip speed ratio, $N$ is the number of blades, and $C_{L}$ is the lift coefficient. The power coefficient $\left(C_{p}\right)$ of the turbine is determined from the following equation [15]:

$$
\begin{aligned}
C_{p}= & \frac{8}{\lambda_{R} N} \sum_{i=k}^{N} F_{i} \sin ^{2} \varphi_{i}\left(\cos \varphi_{i}-\lambda_{r i} \sin \varphi_{i}\right) \\
& \cdot\left(\sin \varphi_{i}+\lambda_{r i} \cos \varphi_{i}\right)\left[1-\frac{C_{D}}{C_{L}} \cos \varphi_{i}\right] \lambda_{r i}{ }^{2},
\end{aligned}
$$

where $F$ is Prandtl's correction factor, $\varphi$ is the angle between the resultant velocity and the rotor plane, and $C_{D}$ is the drag coefficient.
3.1. Corrections. In (12), $F$ is Prandtl's correction factor. This factor is calculated as [16]

$$
\begin{aligned}
& F=\frac{2}{\pi} \cos ^{-1}\left(e^{-f}\right), \\
& f=\frac{N}{2} \frac{R-r}{r \sin \varphi}=\frac{N}{2} \frac{1-r / R}{(r / R) \sin \varphi} .
\end{aligned}
$$

Another correction applied to the modeling is based on the Reynolds number. For the variable range of the Reynolds number, Hernandez and Crespo [17] suggested a correction in which the lift coefficient remains unchanged and the drag coefficient is corrected:

$$
C_{D}=C_{D, \text { ref }}\left(\frac{\operatorname{Re}_{\mathrm{ref}}}{\operatorname{Re}}\right)^{0.2} .
$$

$\mathrm{Re}_{\text {ref }}$ is the Reynolds number in which the drag coefficient $\left(C_{D, \text { ref }}\right)$ of the blade is computed and Re is the Reynolds number based on the working conditions.

Glauert correction is also applied in this modeling to calculate the induced velocities.

\section{Economic Modeling}

Economic analysis is developed based on the Annualized Cost of System (ACS). In this method, revenues and costs are converted to a uniform annuity payment. ACS is the combination of annualized capital cost $\left(C_{\text {acap }}\right)$, annualized replacement cost $\left(C_{\text {arep }}\right)$, annualized maintenance cost $\left(C_{\text {amain }}\right)$, and annualized operating cost $\left(C_{\text {aope }}\right)$ [18].

$$
\begin{aligned}
& \text { ACS } \\
& \begin{aligned}
= & \left.C_{\text {acap }} \text { (total instrument }\right) \\
& +C_{\text {arep }} \text { (total instrument) } \\
& \left.+C_{\text {amain }} \text { (total instrument }\right) \\
& +C_{\text {aope }}(\text { labor cost }+ \text { fuel cost }+ \text { insurance cost }) .
\end{aligned}
\end{aligned}
$$

Annualized capital cost of the system is

$$
\begin{aligned}
C_{\text {acap }} & =C_{\text {cap }} \cdot \operatorname{CRF}\left(i, Y_{\text {proj }}\right), \\
\operatorname{CRF}\left(i, Y_{\text {proj }}\right) & =\frac{i(1+i)^{Y_{\text {proj }}}}{(1+i)^{Y_{\text {proj }}-1}} .
\end{aligned}
$$

$C_{\text {cap }}$ is the capital cost of each component in terms of US dollar and $Y_{\text {proj }}$ is the lifetime of each component in terms of years. The rate of payback (CRF) calculates the present value of the annual cost (a set of annual homogeneous cash flows). The annual real interest rate $(i)$ is

$$
i=\frac{j-f}{1+f} .
$$

In (17), $f$ is annual inflation rate and $j$ is the nominal interest rate. For an initial cost of equipment, see Table 3. 
TABLE 3: Initial capital costs of instruments ([18-20]).

\begin{tabular}{lc}
\hline Component & Cost \\
\hline Compressor & $C_{\text {comp }}=91562\left(\frac{\dot{W}_{\text {comp }}}{445}\right)^{0.67}$ \\
Heat exchanger & $C_{\mathrm{HX}}=8500+409\left(A_{\mathrm{HX}}\right)^{0.85}$ \\
IRSOFC & $C_{\mathrm{SOFC}}=\left(n_{\text {cells }} \pi D_{\text {cell }} L_{\text {cell }}\right)\left(2.96 T_{\text {cell }}-1907\right)$ \\
IRSOFC auxiliary component & $C_{\text {aux, SOFC }}=0.1 C_{\mathrm{SOFC}}$ \\
Inverter & $C_{\text {inv }}=10^{5}\left(\frac{\dot{W}_{\text {cell }}}{500}\right)^{0.7}$ \\
GT & $C_{\mathrm{GT}}=\dot{W}_{\mathrm{GT}}\left(-98.328 \ln \left(\dot{W}_{\mathrm{GT}}\right)+1318.5\right)$ \\
Combustion chamber & $\left(1+\exp \left(0.018 T_{\mathrm{GT}}-26.4\right)\right) \times\left(\frac{46.08 \dot{m}_{\mathrm{cc}}}{0.995-P_{\mathrm{GT}} / P_{\mathrm{cc}}}\right)$ \\
HAWT & $C_{\mathrm{cc}}=(\$ \mathrm{~kW})$ \\
PHS & $1300(\$ / \mathrm{kW})$ \\
\hline
\end{tabular}

The annual replacement cost for this project is considered to be zero; that means the lifetime of the components is equal to the lifetime of the project. For each element, 5\% of the initial cost is considered for the cost of the maintenance [18].

The annual costs of labor, fuel, and insurance are considered as the annual operating costs [18].

4.1. Net Present Value (NPV). The NPV in the engineering economics is one of the standard methods to evaluate the economic plans:

$$
\mathrm{NPV}=\frac{\mathrm{ACS}}{\operatorname{CRF}\left(i, Y_{\text {proj }}\right)}
$$

NPV is the present value of installing and operating the system over its lifetime in a project. The higher the amount of NPV is, the more profitable the project is. If NPV is negative, the project will lose money and it is infeasible in terms of economics [18].

4.2. Levelized Cost of Product (LCOP). The LCOP is the average cost of total usable power production capacity of the system [18]:

$$
\mathrm{LCOP}=\frac{\mathrm{ACS}}{\mathrm{SOPC}}
$$

The SOPC is Summation of Product Costs in a year.

4.3. Other Economic Parameters. Since the LCOP is based on total cost in the lifetime of the project, the Prime Cost (PC) is used based on the market price [18]:

$$
\mathrm{PC}=\frac{\mathrm{OFC}}{\mathrm{VOP}}
$$

The OFC or Operating Flow Costs include operating cost, fuel cost, labor cost, and the insurance cost for a year. The VOP is the Volume of Product in a year.

The period of return (POR) is the ratio of the capital costs to the Net Annual Benefit (NAB). Projects with a shorter
POR are more attractive for the investment compared to plans which have longer periods. The POR means the total time to earn the entire initial capital by the profit [18]:

$$
\mathrm{POR}=\frac{C_{\text {Cap }}}{\mathrm{NAB}} .
$$

$C_{\text {Cap }}$ is the capital cost. The NAB is the subtraction of income taxes from Annual Benefit (AB). AB can be calculated as [18]

$$
\mathrm{AB}=\mathrm{SOPC}-\mathrm{OFC}
$$

\section{Validation}

5.1. IRSOFC. The modeled fuel cell is validated with a model proposed by Pirkandi et al. [10] (Figures 2(a)-2(d)). The fuel cell was run based on Pirkandi et al.'s [10] condition which was a tubular fuel cell at $1273 \mathrm{~K}$ and $100 \mathrm{kPa}$ with 0.85 of fuel utilization factor and $9000 \mathrm{~A} / \mathrm{m}^{2}$ of limiting current density. The fuel composition was $97 \%$ methane, $1.5 \%$ carbon dioxide, and $1.5 \%$ nitrogen. The air composition was $21 \%$ oxygen and $79 \%$ nitrogen. In Figure 2, the variation of total voltage and overpotentials are compared with the results of Pirkandi et al. [10]. Since the compared curves are close, the current model is valid and reliable. Increasing the current density $(i)$ enriches the overpotential values (Figures $2(\mathrm{a})-2(\mathrm{c})$ ), resulting in decreasing the cell voltage (Figure $2(\mathrm{~d})$ ).

5.2. HAWT. The home code is validated by the experimental work of Khalfallah and Koliub [21] for a three-bladed HAWT. The current home code was run for the referred conditions. The output powers from the home code were compared with the results of Khalfallah and Koliub [21] from cut-in wind speed to the designed wind speed, where the maximum power is accessible. As it is shown in Figure 3, the overall agreement between two curves is visible.

\section{Results and Discussion}

The required power for the targeted village is $320 \mathrm{~kW}$, but, in this study, the generated power of $347 \mathrm{~kW}$ is considered. 


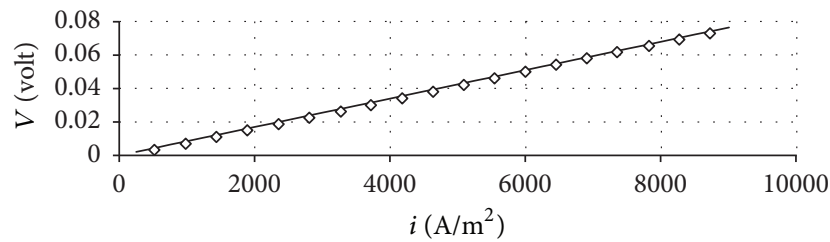

$\diamond \quad$ Ohmic, Pirkandi et al. [10]

— Ohmic, current model

(a)

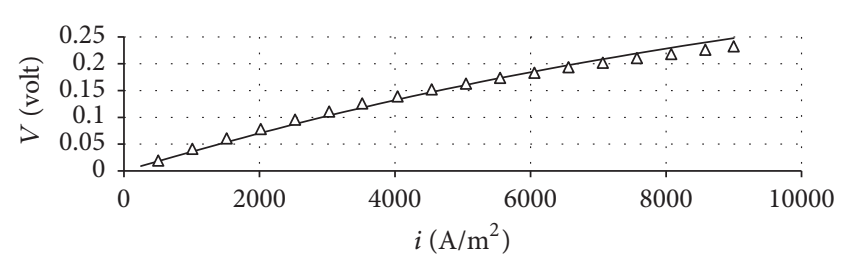

$\Delta \quad$ Activation, Pirkandi et al. [10]

_ Activation, current model

(c)

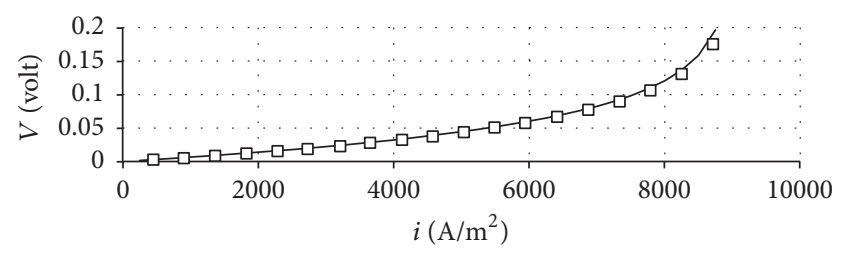

Concentration, Pirkandi et al. [10]

_ Concentration, current model

(b)

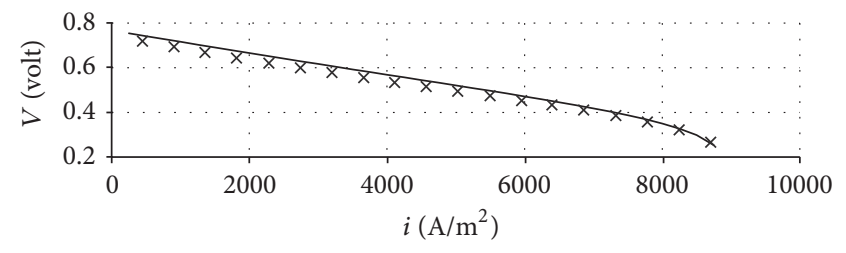

$\times \quad$ CellVoltage, Pirkandi et al. [10]

CellVoltage, current model

(d)

FIGURE 2: IRSOFC validation: (a) ohmic overpotential, (b) concentration overpotential, (c) activation overpotential, and (d) cell voltage.

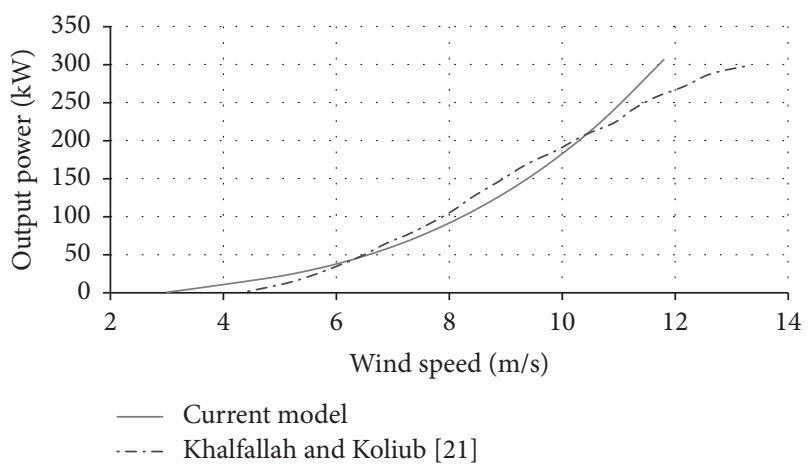

FIgURE 3: Validation of HAWT.

Then, based on $347 \mathrm{~kW}$ power which is assumed to be the targeted power demand, an IRSOFC and a HAWT are modeled.

6.1. Designed HAWT. Based on 10-year NASA records [22], the monthly averaged wind speeds at 50 meters above the surface of the earth for Manjil, north of Iran, were extracted. According to these data, a stall regulated wind turbine with nominal wind speed at $7.9 \mathrm{~m} / \mathrm{s}$ is chosen. For the selection of airfoils, the blade is divided into three parts. An airfoil from the S-serious NREL families is selected for each part.

The details of the design of the wind turbine for two scenarios are provided in Table 4 . As it was mentioned in the second scenario (off-grid IRSOFC-HAWT-PHS) the size of HAWT will increase because of the PHS efficiency and energy loss. The rated power of the HAWT for the first scenario is $347 \mathrm{~kW}$. For the second scenario, the rated power is increased about $30 \%$.

The chosen airfoil profiles were shown in Figure 4 . The S818 airfoil, a thin airfoil, is used at the tip to absorb the

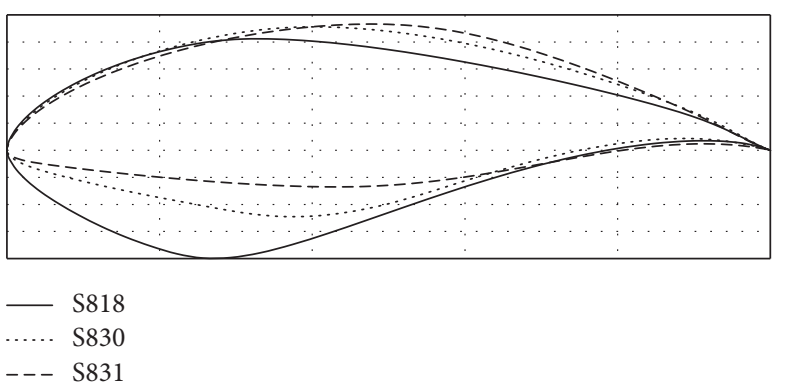

Figure 4: Selected airfoils.

TABLE 4: Details of the modeled HAWT.

\begin{tabular}{lcc}
\hline & First scenario & Second scenario \\
\hline Tip speed ratio & 6 & 6 \\
Number of blades & 3 & 3 \\
Rotor diameter $(\mathrm{m})$ & 58.14 & 66.14 \\
Blade radius $(\mathrm{m})$ & 26.67 & 30.34 \\
Hub height $(\mathrm{m})$ & 50 & 50 \\
Airfoils & S818, S830, S831 & S818, S830, S831 \\
\hline
\end{tabular}

maximum power. From the tip to the root, the airfoils become thicker. S830 and S831 are the airfoils used for the mid and the root of the blade, respectively. The variations of blade pitch $(\varphi)$ and the chord during the blade are shown in Figure 5. The behaviors of both scenarios are almost the same.

After designing the HAWT and based on the wind speed variations, monthly power generation from the HAWT for both scenarios is shown in Figure 6. Because of the low wind speed from September to February, the power production of the HAWT has the lowest values in these months. In July and August, the power reaches its maximum values as the wind is so strong. 


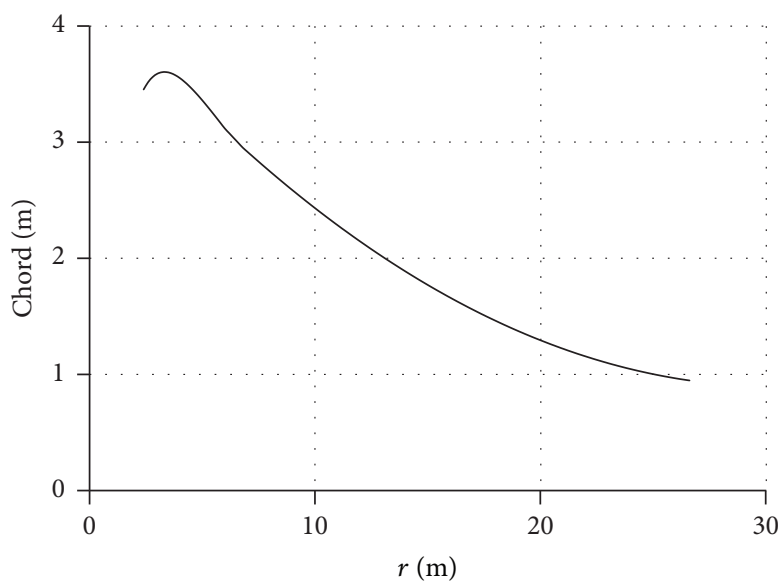

(a)

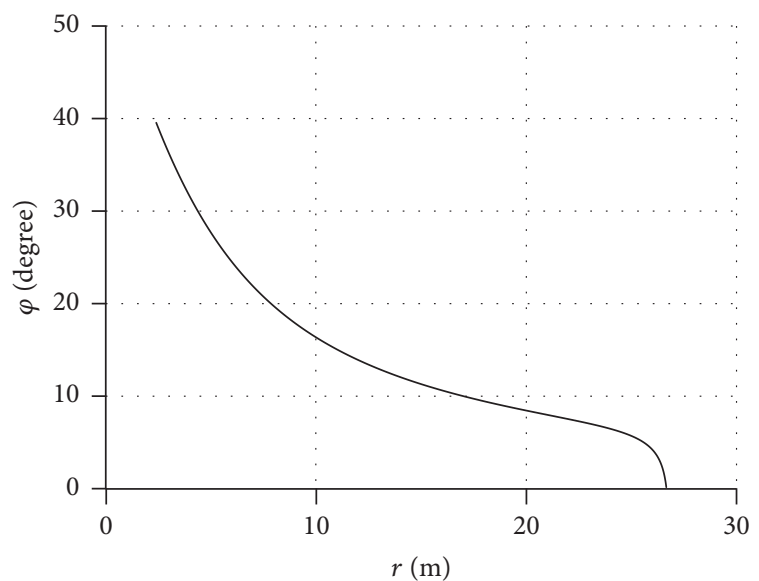

(b)

FIgURE 5: Variation of (a) chord and (b) $\varphi$ during the blade.

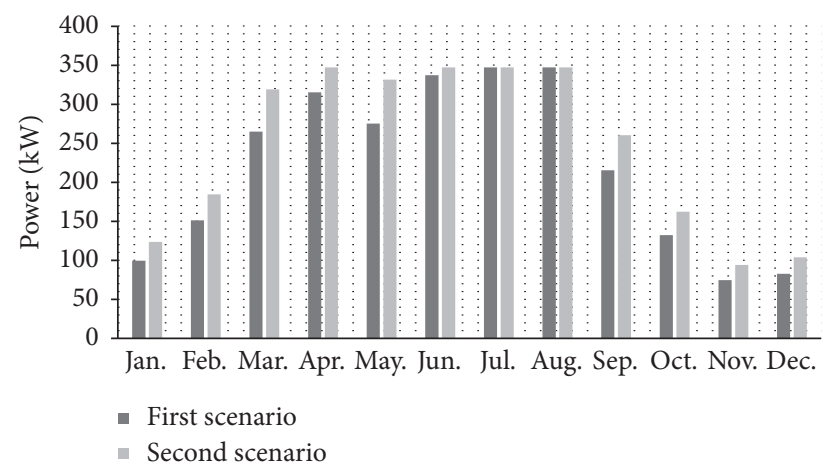

Figure 6: Monthly power generation from the HAWT.

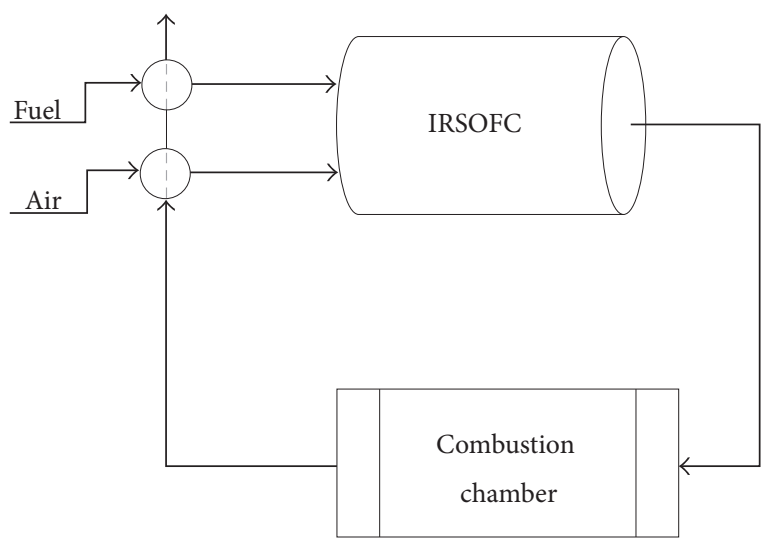

FIGURE 7: A schematic of the IRSOFC cycle.

6.2. IRSOFC Model. IRSOFC works at 1 bar pressure. The fuel that is fed to the IRSOFC is methane. A schematic of it is shown in Figure 7. The details of the IRSOFC inputs are provided in Table 5.

According to the power generated by the wind turbine during a year (Figure 6), the rest of the needed power should

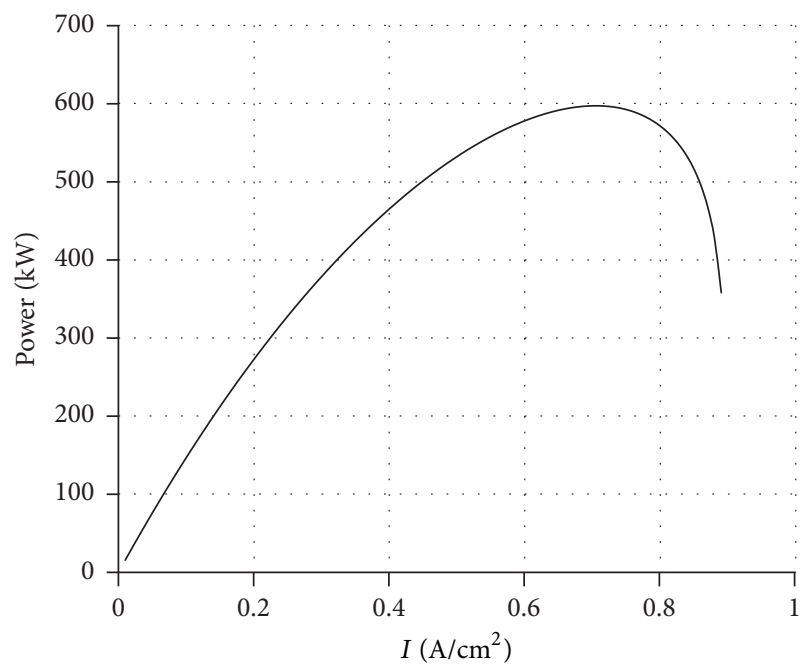

FIGURE 8: Variation of IRSOFC power production versus current density (first scenario).

be generated by the IRSOFC. The results of IRSOFC modeling for both scenarios are shown in Table 6. The fuel flow rate in Table 6 is based on a full load operation. The IRSOFC does not work under full load all the time but using full load fuel flow rate for the whole year in economic analysis will provide a safety margin that the village will always have stable electricity.

In the second scenario, the size of the PHS equals $94 \mathrm{~kW}$, which is the difference between the power demand and the IRSOFC capacity. Power and efficiency variation versus current density for the first scenario are shown in Figures 8 and 9, respectively. There is no significant difference between the results of two scenarios. As it is shown, increasing current density (up to $0.65 \mathrm{~A} / \mathrm{cm}^{2}$ ) increases the power but decreases the efficiency of the system because the fuel consumption strongly depends on the current density. Thus, the current density of IRSOFC is set to $2000 \mathrm{~A} / \mathrm{m}^{2}$. 


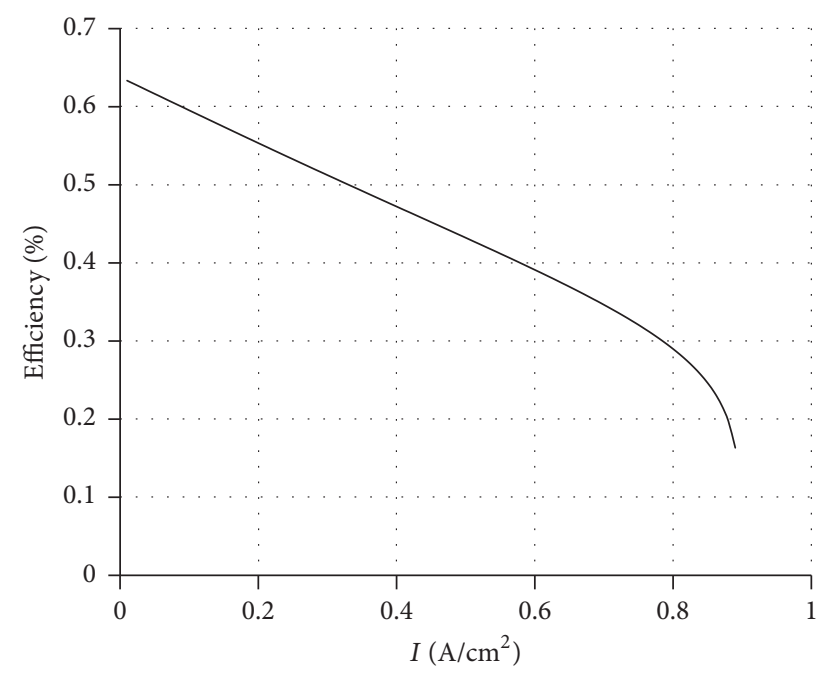

FIGURE 9: Variation of IRSOFC efficiency versus current density (first scenario).

TABLE 5: Input parameters for IRSOFC system.

\begin{tabular}{lcc}
\hline \multicolumn{3}{c}{ Component efficiency } \\
\hline Combustion chamber & 95 & $\%$ \\
Heat exchanger & 80 & $\%$ \\
Inverter & 96.5 & $\%$ \\
\hline \multicolumn{4}{c}{ Pressure drop } & $\%$ \\
\hline SOFC & 1 & $\%$ \\
Combustion chamber & 2 & $\%$ \\
\hline & 1 & \\
\hline Area & SOFC input data & $\mathrm{m}^{2}$ \\
Recirculation ratio & 0.0834 & $\%$ \\
Limiting current density & 60 & $\mathrm{~A} / \mathrm{m}^{2}$ \\
Current density & 9000 & $\mathrm{~A} / \mathrm{m}^{2}$ \\
Fuel utilization factor & 2000 & $\%$ \\
Air utilization factor & 85 & $\%$ \\
\hline
\end{tabular}

TABLE 6: Results of IRSOFC modeling.

\begin{tabular}{lccc}
\hline & & First scenario & Second scenario \\
\hline Electrical efficiency & $\%$ & 55.3 & 55.3 \\
Number of cells & & 2554 & 2371 \\
SOFC power production & $\mathrm{kW}$ & 272.5 & 253.0 \\
Fuel flow rate & $\mathrm{kg} / \mathrm{s}$ & 0.0099 & 0.0091 \\
\hline
\end{tabular}

6.3. Economic Study. It is assumed that government is going to run this project. The goal is to compare the current results with those from the conventional methods to produce electricity. Therefore, the electricity price and the fuel price are considered based on the prices for the government. For inputs and conditions, see Table 7.

Because of the size of the systems, grid connection cost (first scenario), and the PHS cost (second scenario), the economic results from two scenarios are different. The wind farm price is divided into $69 \%$ for the turbine, $12 \%$ for the
TABLE 7: Economic parameter.

\begin{tabular}{lcc}
\hline Number of labors & 3 & \\
Labor's salary & 500 & $\$ /$ month \\
Project lifetime & 20 & Year \\
Price of products & 0.0879 & $\$ / \mathrm{kWh}$ \\
Interest rate & 22 & $\%$ \\
Annual inflation rate & 15.6 & $\%$ \\
Tax & 8 & $\%$ \\
Fuel price & 0.23 & $\$ / \mathrm{m}^{3}$ \\
\hline
\end{tabular}

TABLE 8: Economic results.

\begin{tabular}{lccc}
\hline & & First scenario & Second scenario \\
\hline ACS & $\$$ & $2.2709 \times 10^{5}$ & $2.6833 \times 10^{5}$ \\
$C_{\text {acap }}$ & $\$$ & $1.0919 \times 10^{5}$ & $1.3206 \times 10^{5}$ \\
$C_{\text {arep }}$ & $\$$ & 0 & 0 \\
$C_{\text {amain }}$ & $\$$ & $6.5046 \times 10^{4}$ & $7.8674 \times 10^{4}$ \\
$C_{\text {aope }}$ & $\$$ & $5.2854 \times 10^{4}$ & $5.7591 \times 10^{4}$ \\
$\mathrm{LCOP}$ & $\$ / \mathrm{kWh}$ & 0.0747 & 0.0882 \\
$\mathrm{NPV}$ & $\$$ & $2.7056 \times 10^{6}$ & $3.1970 \times 10^{6}$ \\
$\mathrm{AB}$ & $\$$ & $1.4941 \times 10^{5}$ & $1.3104 \times 10^{5}$ \\
$\mathrm{PC}$ & $\$ / \mathrm{kWh}$ & 0.0388 & 0.0448 \\
$\mathrm{POR}$ & Year & 9.4645 & 13.0515 \\
\hline
\end{tabular}

grid connection, $8 \%$ for the foundation, $3 \%$ for the internal grid, $3 \%$ for the installation, and $5 \%$ for the rest [23]. For the second scenario, the cost of grid connection is replaced by the PHS cost. The results of the economic analysis are shown in Table 8.

All economic parameters are dominated by the capital cost which is the highest in the second scenario. The POR and the PC for the second scenario are about 38\% and 15\% higher than those of the first one, respectively. Thus, because of the capital cost of the PHS system, the first scenario is more economical than the second scenario.

In both projects, $\mathrm{PC}$ is lower than the price of electricity (POP); in the first scenario, PC is $126 \%$ lower than POP and, in the second scenario, this number is $96 \%$, which is the advantage of using renewable energies with low energy costs.

Figure 10 shows the effects of the real interest rate on economic parameters. Increasing the real interest rate decreases the NPV and increases the LCOP and the ACS of the system (Figure 10). The slopes of the curves for the second scenario are higher than those of the first scenario. The real interest rate for the current project is 0.0554 (Figure 11), which is a high value; the detailed values are provided in Table 7 for Iran. That means, in countries with the low values of the real interest rate, the project will be more profitable in particular for the second scenario. For example, 10\% lessening the real interest rate can improve all parameters about 2\% (Figure 10). As it is seen, the economic parameters are not too sensitive to real interest rate.

The value of POP for this project is 0.0879 (Table 7), which is shown in Figure 11. For this project, the period of return (POR) is 9.46 years for the first scenario and 13.05 years for the second one. In Figure 11, the slopes of the curves at the 

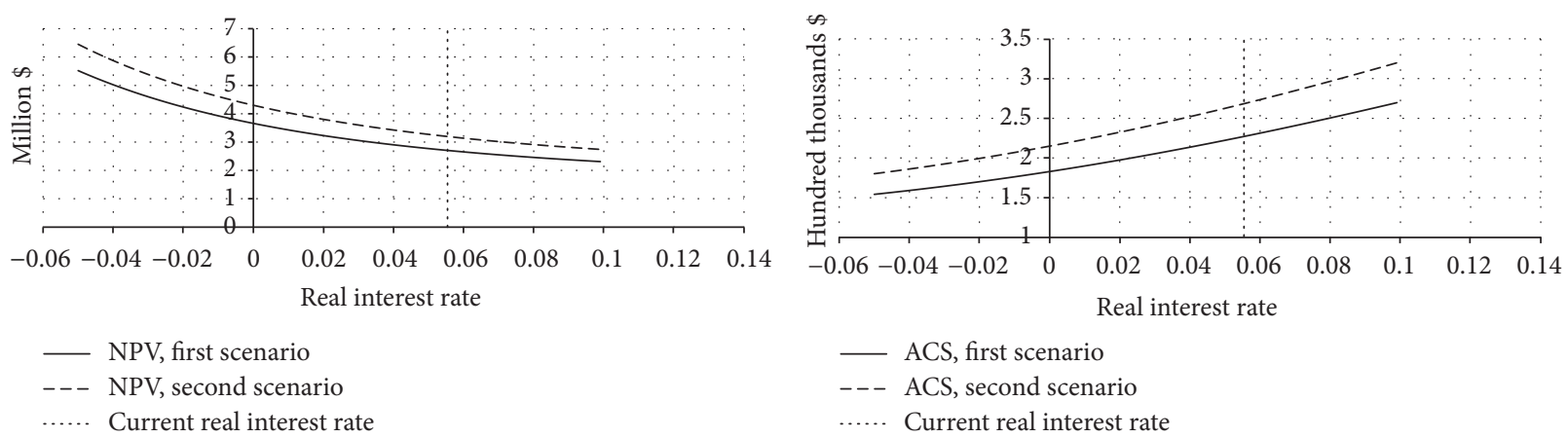

(a)

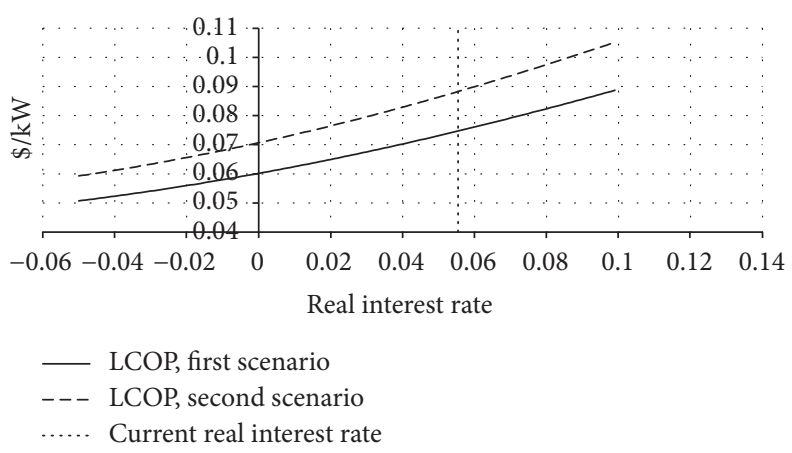

(c)

Figure 10: Variation of (a) NPV, (b) ACS, and (c) LCOP versus real interest rate.

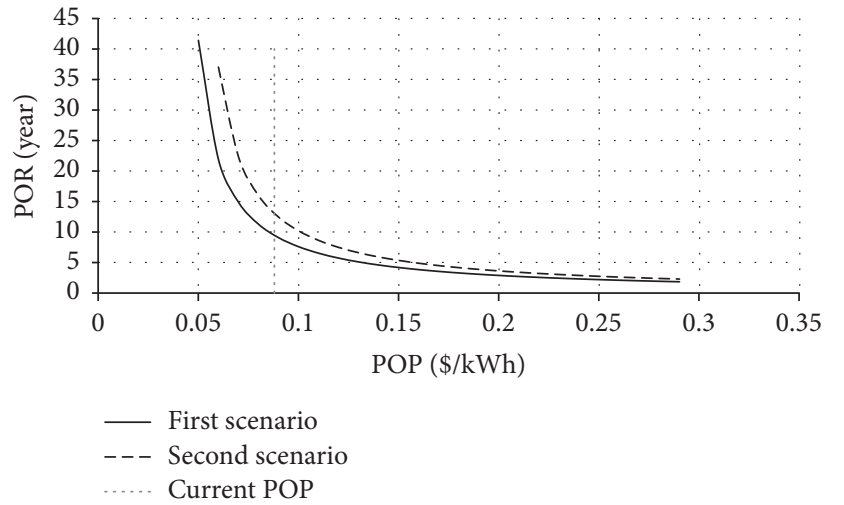

FIgURE 11: Variation of POR versus POP.

beginning are very high; then, small changes in the POP can make significant changes in the POR. For the second scenario, about $15 \%$ increase in POP decreases the POR under 10 years making the project more economical.

\section{Conclusion}

For a combined IRSOFC-HAWT system, thermodynamic and economic analyses were done based on two scenarios: an on-grid-IRSOFC-HAWT system and an off-grid-IRSOFCHAWT system with a PHS. Based on the thermodynamic analysis, the best working condition for the IRSOFC was chosen and then a proper HAWT was designed to generate the demand power of a village in Manjil, Iran. The high capital cost of the PHS dominated the economic parameters and made the second scenario the worst one from the economic point of view. The POR for the second scenario is about 3 years longer compared to that of the first scenario which was 9.46 years. Although the second scenario is less economical, for the case of having no access to the grid, this scenario makes the project possible. If the price of the electricity or the POP was increased only $15 \%$, around $30 \%$ of the years of the POR would be reduced, making the second scenario more economical. In both projects, $\mathrm{PC}$ is lower than the price of electricity (POP), which is the advantage of using renewable energies with low energy costs.

It is suggested for the future work of this study that the waste heat of the system be used directly for the heating and cooling purposes, making both scenarios more profitable.

\section{Nomenclature}

A: $\quad$ Area $\left[\mathrm{m}^{2}\right]$

AB: Annual Benefit [\$]

$A, B$ : Constants [-]

ACS: Annualized Cost of System [\$]

c: $\quad$ Chord $[\mathrm{m}]$

C: Cost [\$]

$C_{D}:$ Drag coefficient [-]

$C_{L}: \quad$ Lift coefficient [-]

$C_{p}$ : Power coefficient [-]

CRF: Capital Recovery Factor [-]

$D: \quad$ Diameter $[\mathrm{m}]$

E: Cell voltage [V] 


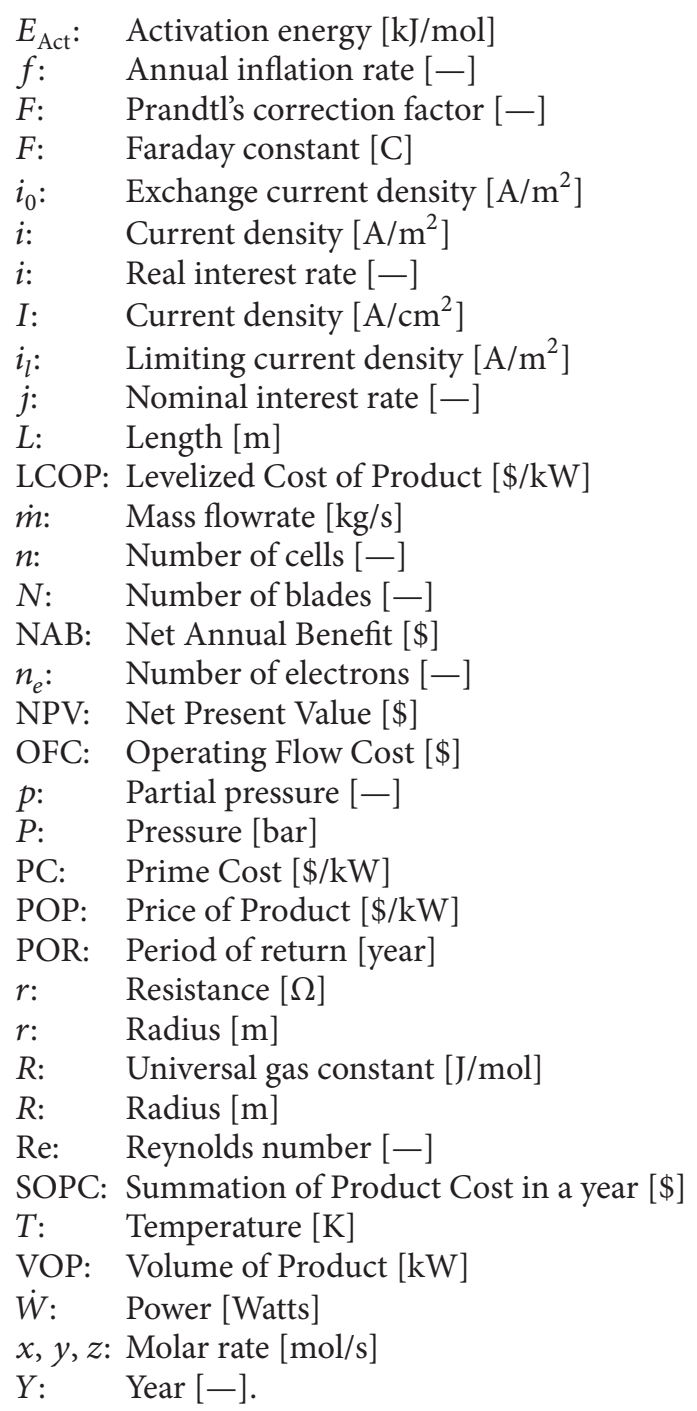

\section{Greek Letters}

$\beta$ : $\quad$ Heat transfer coefficient [-]

$\gamma: \quad$ Preexponential factor $\left[\mathrm{A} / \mathrm{m}^{2}\right]$

$\delta: \quad$ Thickness [cm]

$\Delta G^{\circ}$ : Gibbs free energy changes at standard condition [-]

$\eta: \quad$ Overpotential [V]

$\lambda_{r}:$ Tip speed ratio at radius $r[-]$

$\rho: \quad$ Resistivity $[\Omega \cdot \mathrm{cm}]$

$\varphi$ : Angle between the resultant velocity and the rotor plane [degree].

\section{Subscript}

acap: Annualized capital cost

Act: Activation

amain: Annualized maintenance cost

An: Anode

aope: Annualized operating cost

arep: Annualized replacement cost

Ca: Cathode

Cap: Capital

cc: Combustion chamber

$\begin{array}{ll}\text { comp: } & \text { Compressor } \\ \text { Conc: } & \text { Concentration } \\ \text { GT: } & \text { Gas turbine } \\ \text { HX: } & \text { Heat exchanger } \\ i: & \text { Section number of the blade } \\ \text { inv: } & \text { Inverter } \\ \text { proj: } & \text { Project } \\ \text { ref: } & \text { Reference } \\ \text { rep: } & \text { Replacement } \\ \text { rev: } & \text { Reversible. }\end{array}$

\section{Conflicts of Interest}

The authors declare that they have no conflicts of interest.

\section{References}

[1] S. Soheyli, M. H. Shafiei Mayam, and M. Mehrjoo, "Modeling a novel CCHP system including solar and wind renewable energy resources and sizing by a CC-MOPSO algorithm," Applied Energy, vol. 184, pp. 375-395, 2016.

[2] A. Fathy, "A reliable methodology based on mine blast optimization algorithm for optimal sizing of hybrid PV-wind-FC system for remote area in Egypt," Renewable Energy, vol. 95, pp. 367380, 2016.

[3] S. Obara, J. R. Morel Rios, and M. Okada, "Control of cyclic fluctuations in solid oxide fuel cell cogeneration accompanied by photovoltaics," Energy, vol. 91, pp. 994-1008, 2015.

[4] M. Hosseini, I. Dincer, and M. A. Rosen, "Hybrid solar-fuel cell combined heat and power systems for residential applications: Energy and exergy analyses," Journal of Power Sources, vol. 221, pp. 372-380, 2013.

[5] T. Vigneysh and N. Kumarappan, "Autonomous operation and control of photovoltaic/solid oxide fuel cell/battery energy storage based microgrid using fuzzy logic controller," International Journal of Hydrogen Energy, vol. 41, no. 3, pp. 1877-1891, 2016.

[6] D. Tenfen and E. C. Finardi, "A mixed integer linear programming model for the energy management problem of microgrids," Electric Power Systems Research, vol. 122, pp. 19-28, 2015.

[7] R. K. Akikur, R. Saidur, H. W. Ping, and K. R. Ullah, "Performance analysis of a co-generation system using solar energy and SOFC technology," Energy Conversion and Management, vol. 79, pp. 415-430, 2014.

[8] W. Bai, M. R. Abedi, and K. Y. Lee, "Distributed generation system control strategies with PV and fuel cell in microgrid operation," Control Engineering Practice, vol. 53, pp. 184-193, 2016.

[9] S. H. Chan, H. K. Ho, and Y. Tian, "Modelling of simple hybrid solid oxide fuel cell and gas turbine power plant," Journal of Power Sources, vol. 109, no. 1, pp. 111-120, 2002.

[10] J. Pirkandi, M. Ghassemi, M. H. Hamedi, and R. Mohammadi, "Electrochemical and thermodynamic modeling of a CHP system using tubular solid oxide fuel cell (SOFC-CHP)," Journal of Cleaner Production, vol. 29-30, pp. 151-162, 2012.

[11] J. Larminie and A. Dicks, Fuel Cell Systems Explained, John Wiley \& Sons, West Sussex, UK, 1st edition, 2003.

[12] S. H. Chan, K. A. Khor, and Z. T. Xia, "Complete polarization model of a solid oxide fuel cell and its sensitivity to the change of cell component thickness," Journal of Power Sources, vol. 93, no. 1-2, pp. 130-140, 2001. 
[13] P. Costamagna and K. Honegger, "Modeling of solid oxide heat exchanger integrated stacks and simulation at high fuel utilization," Journal of the Electrochemical Society, vol. 145, no. 11, pp. 3995-4007, 1998.

[14] R. Gasch and J. Twele, Eds., Windkraftanlagen: Grundlagen, Entwurf, Planung und Betrieb, Springer-Verlag, 2010.

[15] J. Manwell, Wind Energy Explained: Theory, Design and Application, 1st edition, 2002.

[16] M. Hansen, Aerodynamics of Wind Turbines, Earthscan, Sterling, VA, USA, 1st edition, 2008.

[17] J. Hernandez and A. Crespo, "Aerodynamic calculation of the performance of horizontal axis wind turbines and comparison with experimental results," Wind Engineering, vol. 11, no. 4, pp. 177-187, 1987.

[18] M. Meratizaman, S. Monadizadeh, and M. Amidpour, "Introduction of an efficient small-scale freshwater-power generation cycle (SOFC-GT-MED), simulation, parametric study and economic assessment," Desalination, vol. 351, pp. 43-58, 2014.

[19] M. Gökçek and M. S. Genç, "Evaluation of electricity generation and energy cost of wind energy conversion systems (WECSs) in Central Turkey," Applied Energy, vol. 86, no. 12, pp. 2731-2739, 2009.

[20] P. Du and N. Lu, Energy Storage for Smart Grids: Planning and Operation for Renewable and Variable Energy Resources (VERs), Academic Press, 2014.

[21] M. G. Khalfallah and A. M. Koliub, "Effect of dust on the performance of wind turbines," Desalination, vol. 209, no. 1-3, pp. 209-220, 2007.

[22] ASDC - Processing, archiving, and distributing Earth science data at the NASA Langley Research Center, https://eosweb.larc .nasa.gov/ [Accessed 5 April 2017].

[23] H. Auer, M. Stadler, G. Resch, T. Schuster, J. Twidell, and D. J. Swider, "Pushing A Least Cost Integration Of Green Electricity Into The European Grid (GreenNet)-Cost and Technical Constraints of RES-E Grid Integration," Tech. Rep., Energy Economics Group, 2006. 


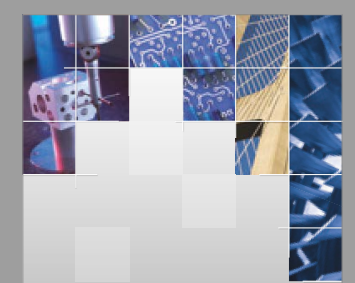

\section{Enfincering}
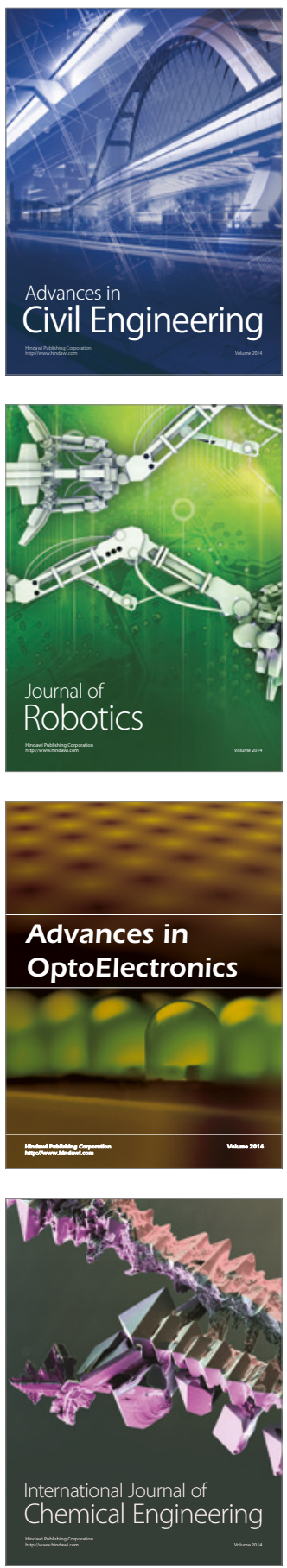

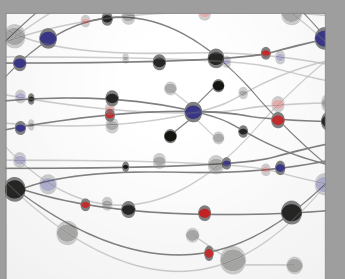

The Scientific World Journal

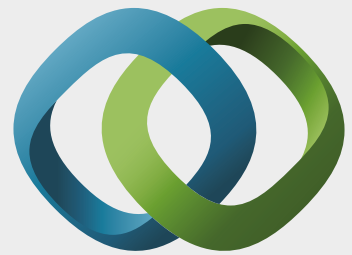

\section{Hindawi}

Submit your manuscripts at

https://www.hindawi.com
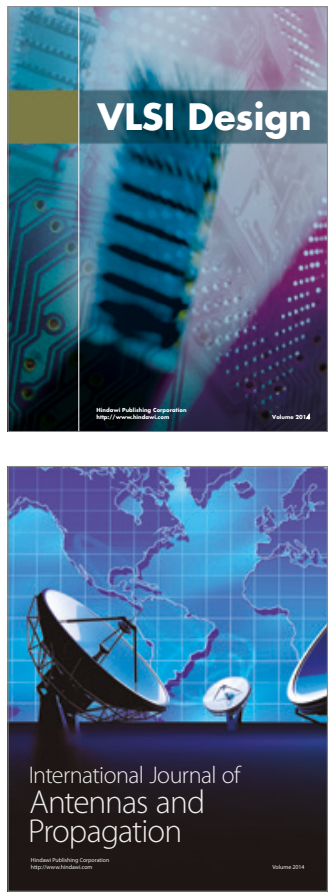

\section{Rotating}

Machinery
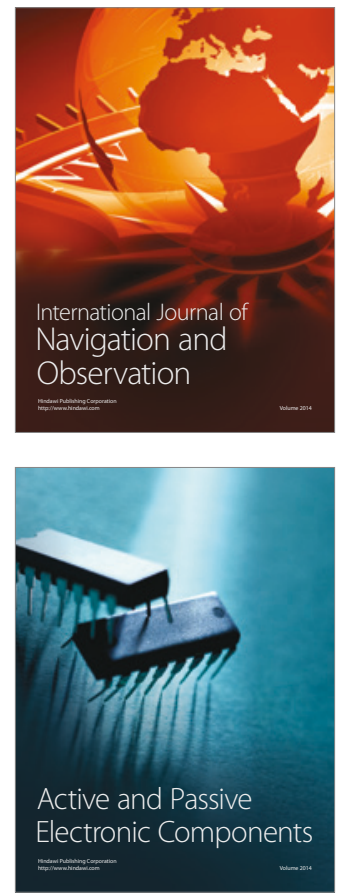
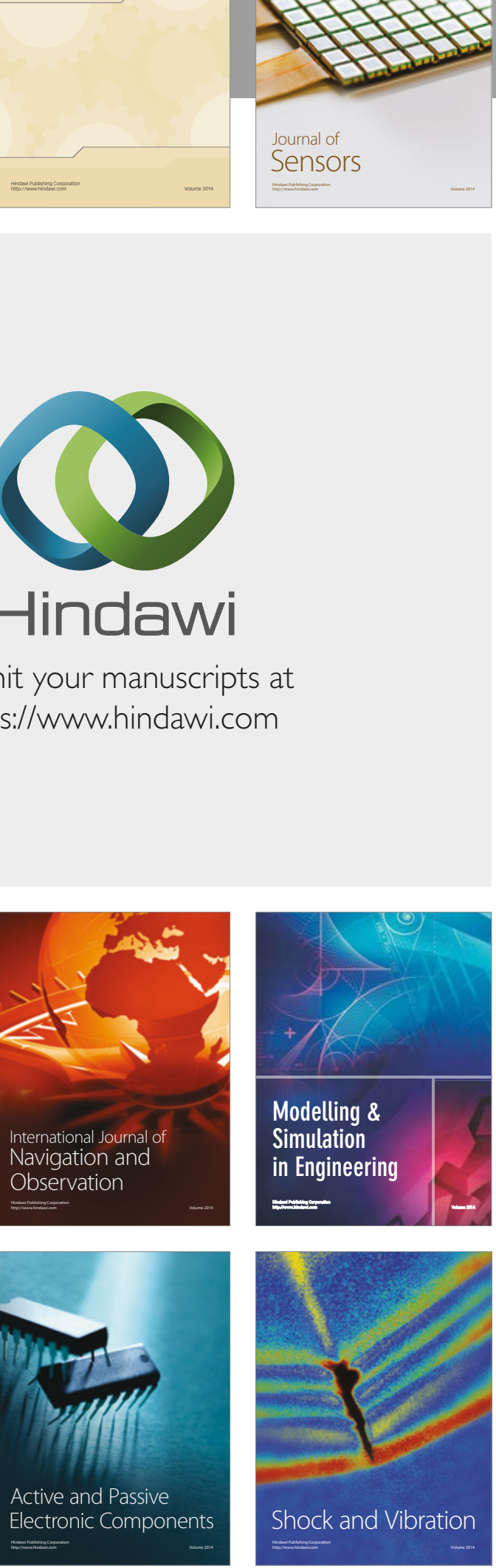
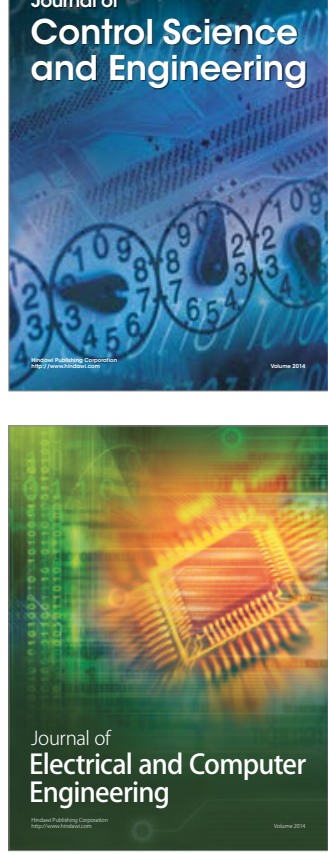

Distributed

Journal of

Control Science

and Engineering
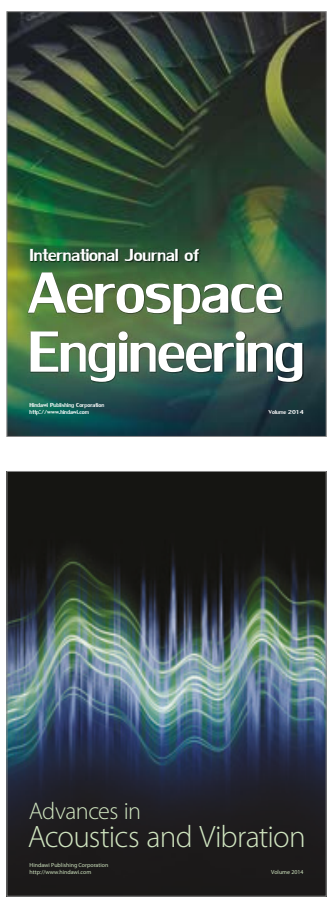

Sensor Networks 